TYMOTEUSZ MILLER*

GORZYSEAW POLESZCZUK*

MALGORZATA TOKARZ*

\title{
CHANGES OF WATER QUALITY OF THE OSÓWKA STREAM FLOWING THROUGH PONDS SYRENIE STAWY IN SZCZECIN (NW-POLAND) IN SELECTED PERIODS IN THE YEARS 1994-2014
}

\begin{abstract}
The aim of discernment changes in water quality of stream Osówka flowing through ponds Syrenie Stawy in Szczecin (NW-Poland) conducted in the years 1994-2014 the study of basic water chemistry indices in the Osówka Stream water inflow and outflow area of water in/from ponds Syrenie Stawy, which were used to calculate the value of the National Sanitation Foundation Water Quality Index (NSF-WQI). The NFS-WQI values were calculated on the basis of temperature, $\mathrm{pH}$, dissolved oxygen (as a percentage of water saturation), $\mathrm{BOD}_{5}$ and concentration of nitrates and total phosphates carried out in 1994-1995, 1999-2000, 2006-2007 and 2014, i.e. during time periods, and in particular the decrease in the amount of inflowing industrial pollution and the changes of anthropopressure related to the hydrotechnical works of stream Osówka and ponds Syrenie Stawy. In assessing according to the criteria of NFS WQI procedure - studied water quality corresponded good and medium to average quality. On the basis of the values and changes in values of NSF-WQI it has been shown that quality
\end{abstract}

* Department of Chemistry and Natural Water Management, University of Szczecin, Felczaka 3c, 71-412 Szczecin, Poland, e-mail: polesz@univ.szczecin.pl 
water flowing through ponds Syrenie Stawy in subsequent periods the was getting worse, while self-cleaning effect of the waters along the ponds Syrenie Stawy gradually increase, especially after hydrotechnical works. It has been estimated that the NSF-WQI procedure to assess the quality and discerning water quality changes in the flow ponds in long-time period, based on the basic physical and chemical water quality indices - can be useful to use in practice.

Keywords: urban ponds, water quality index NSF-WQI, Osówka Stream, ponds Syrenie Stawy, Szczecin City

\section{Introduction}

In the European Union countries to the surface waters quality assessment is carried out according to the principles set out in the Water Framework Directive (European Commission 2008) and by detailed official procedures contained in the relevant regulations in the EU countries. In Poland currently in Regulation of Minister of Environment Protection (Regulation 2014). Above procedures for assessing surface water quality based primarily on the quality of biocenosis and only supported on a small number of physicochemical water quality indices.

In countries outside the European Union the problem of assessing the quality of surface waters is solved by determining (calculating) the water quality index (WQI), often calculated according to slightly different rules (Brown et al. 1970; Cude 2001, Sanchez et al. 2007; Dos Santos et al. 2008; Rai et al. 2012, Javid 2015; Farzadkia et al. 2015; Tallar, Suen 2015). The main advantage of WQI is that it can be relatively easy to calculate on the basis of measuring a small number of water quality indices, primarily - physicochemical and to a lesser extent biological agents.

The use of indices to assess the water quality of surface water quality was before the Polish accession to the European Union - also used in Poland (Zdunkiewicz 1981; Dojlido et al. 1994).

The aim of this study was to attempt assessment of changes in water quality of Osówka Stream flowing through ponds Syrenie Stawy in Szczecin (Figs. 1, 2) during period 1994-2014, based on the collected results of water quality indices measurement data after the calculation of the National Sanitation Foundation Water Quality Index (NSF-WQI) (after Brown et al. 1970; Landwehr, Deininger 1976; Rai et al. 2012). The usefulness of the application NSF-WQI for fast re- 
search - based on small number of water quality indices - to assess changes in water quality ponds studied in long-time period was tested.

Three two-year and one one-year test cycle were chosen, where the choice of measuring years were not accidental. In particular, in 1994-1995 ponds Syrenie Stawy were collecting reservoir - although declining gradually - the quantity of industrial waste water as well as wastewater with wastewater carts in the years 1999-2000 - after reducing (at least formally) discharge of wastewater into ponds Syrenie Stawy, while in 2006-2007 - after the infilling of sediments in 2003 and finally in 2014 - after two years of hydrotechnical works involving inter alia the removal of macrophytes, deepening and strengthening fascine of Syrenie Stawy shores in 2010-2012.

\section{Characteristic of ponds Syrenie Stawy}

Ponds Syrenie Stawy in Szczecin (Fig. 1) are located in the north-western part of the city of Szczecin (53²7’26 N, 14³0’5 E, elevation of the water surface 16.40 $\mathrm{m}$ asl) (Fig. 1). These are the four artificial small water reservoirs currently located in a separate area of special natural and landscape value "The Team Parks Kasprowicz-Arkoński" (Fig. 2) created in the mid-nineteenth century after adjusting the Osówka Stream riverbed when part of the waters flow to the reservoirs by constructed bypass channel and then back to stream Osówka. Ponds Syrenie Stawy fulfill the function of Osówka Stream freshet waters reservoirs, and also function of the biological ponds - after referring waters from storm water drainage system and waste water to ponds Syrenie Stawy. Ponds are small in size (Pond No. 1 approx. 0.15 ha, pond No. 2 approx. 0.75 ha, pond No. 3 approx. 0.12 ha, pond No. 4 approx 0.10 ha - a total of about 1.15 ha) and maximum depth of 1.5 $2.0 \mathrm{~m}$, which are incorporated into the municipal sewer system, playing a role of rain-water-reservoirs. In the above mentioned Ponds filled the muddy sediments of varying thickness over the study period. Ponds No. 1 and 2 are led municipal storm sewer collectors of Szczecin. Especially pond No. 2 were also discharged industrial wastewater from factories and workshops located on Wojska Polskiego Av. ponds Syrenie Stawy to mid-90s of previous century were receiver of wastewater from industrial plants - factory of car mechanisms "POLMO" and military machine workshops. Ponds were also periodically contaminated with sewage discharged from wastewater carts. Input of pollutants has been reduced to a minimum at the end of the 90s (Poleszczuk 2003). 


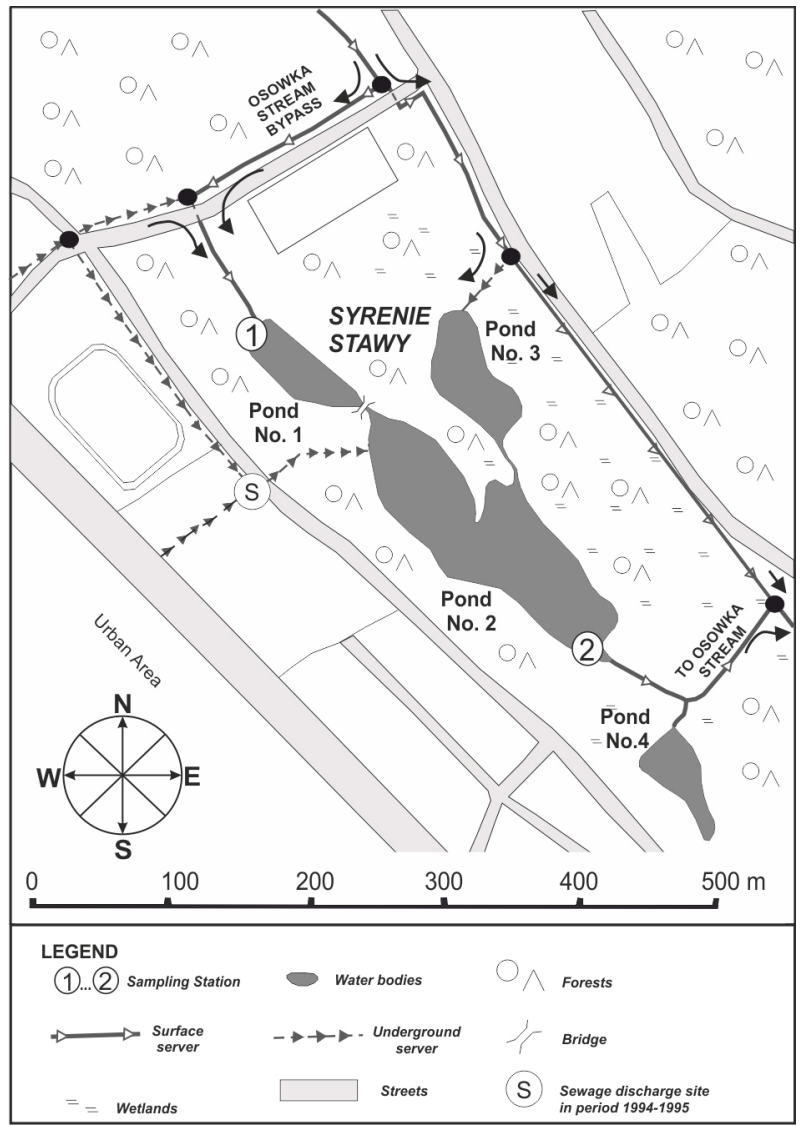

Figure 1. Ponds Syrenie Stawy in Szczecin (NW-Poland)

Source: after Poleszczuk (2003) - with changes.

\section{Material and methods}

Water samples from ponds Syrenie Stawy was drawn from surface layer of water - from a depth of 20-25 cm - in the water inflow area to Pond No.1 (sampling station No. 1) and outflow area of water from the Pond No. 2 (sampling station No. 2) with a once in month frequency, in particularly in years: 1994 from June to December, 1995 from January to December, 1999 and 2000 - from January to December, while in 2006 and 2007 during the period from March to November, and in 2014 - from January to December. Water sampling, preservation, transport and analytical procedures were adequate to the recommendations of the APHA (1992). 
In water samples were determined following water quality indices: temperature, $\mathrm{pH}$, dissolved oxygen (DO), five day biochemical oxygen demand $\left(\mathrm{BOD}_{5}\right)$ and concentrations of nitrates $\left(\mathrm{NO}_{3}\right)$ and total phosphates (TP) - according to the type of indices used for the calculations NSF-WQI (Rai et al. 2012).

Part of water quality investigation results used in this study was presented in earlier publications (Poleszczuk et al. 2014; Miller et al. 2014) (January-June in the subsequent years of research). Calculation of NSF-WQI performed according to calculation procedures presented in Appendix to these paper. All calculations has been done using the software STATISTICA 10.0 PL and Statgraphics Centurion XIV.

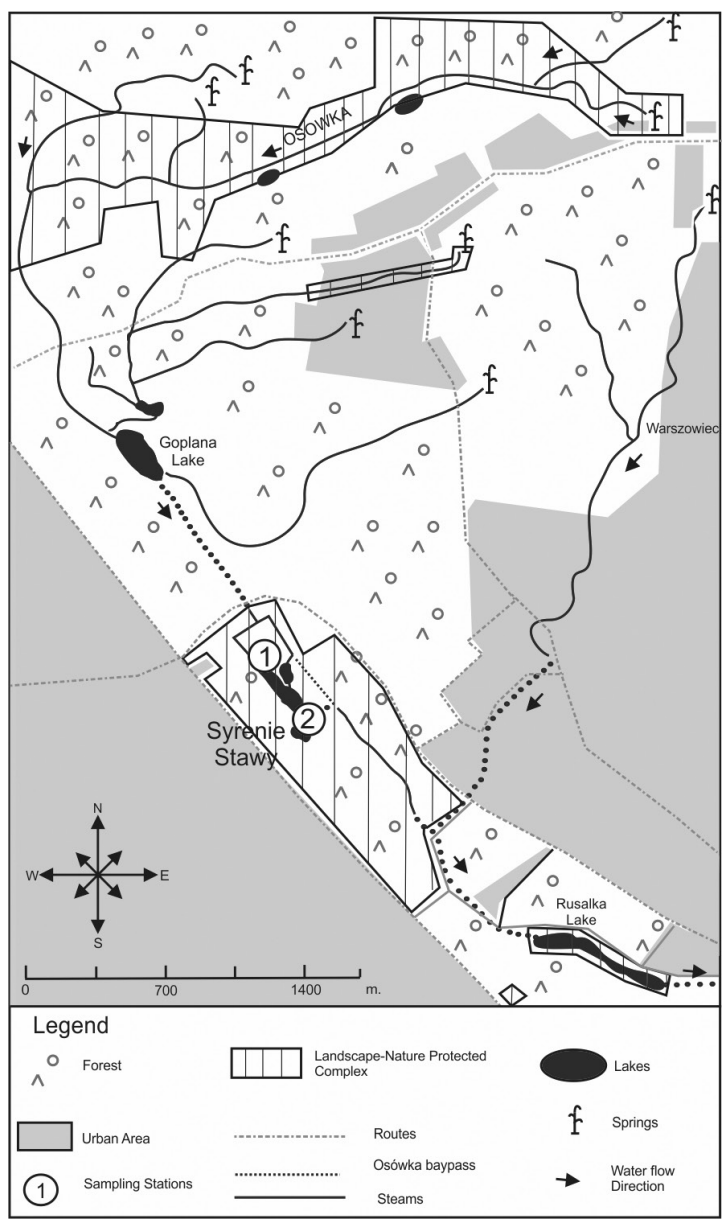

Figure 2. Osówka Stream in Szczecin (NW-Polnad)

Source: after Miller et al. (2014) - with changes. 
Table 1. Statistical characteristics of data sets - inflow waters to Syrenie Stawy (Pond No.1)

\begin{tabular}{|c|c|c|c|c|c|}
\hline \multirow{2}{*}{$\begin{array}{l}\text { Water quality indices } \\
\text { (units) }\end{array}$} & \multirow{2}{*}{$\begin{array}{l}\text { Descriptive } \\
\text { Statistics }\end{array}$} & \multicolumn{4}{|c|}{ Year } \\
\hline & & 1994-1995 & 1999-2000 & $2006-2007$ & 2014 \\
\hline \multirow{3}{*}{$\begin{array}{l}\text { Temperature } \\
\left({ }^{\circ} \mathrm{C}\right)\end{array}$} & Mean \pm SD & $11.8 \pm 7.3$ & $9.9 \pm 5.4$ & $16.3 \pm 4.3$ & $12.8 \pm 7.4$ \\
\hline & Range & $0.5-24.0$ & $3.0-17.2$ & $10.0-24.0$ & $2.6-23.6$ \\
\hline & $\mathrm{CV}$ & 0.62 & 0.54 & 0.26 & 0.58 \\
\hline \multirow{3}{*}{$\begin{array}{l}\mathrm{pH} \\
\text { (pH units) }\end{array}$} & Mean \pm SD & $7.50 \pm 0.61$ & $7.73 \pm 0.20$ & $7.60 \pm 0.56$ & $7.93 \pm 0.73$ \\
\hline & Range & $6.70-8.90$ & $7.15-8.00$ & $6.80-8.75$ & $7.04-9.43$ \\
\hline & $\mathrm{CV}$ & 0.08 & 0.03 & 0.07 & 0.09 \\
\hline \multirow{3}{*}{$\begin{array}{l}\text { DO } \\
\text { (\% saturation) }\end{array}$} & Mean \pm SD & $78.1 \pm 36.0$ & $49.3 \pm 17.5$ & $43.0 \pm 35.3$ & $43.9 \pm 21.5$ \\
\hline & Range & $32.0-191.0$ & $31.0-87.0$ & $11.7-148.0$ & $19.9-82.5$ \\
\hline & $\mathrm{CV}$ & 0.46 & 0.36 & 0.82 & 0.49 \\
\hline \multirow{3}{*}{$\begin{array}{l}\mathrm{BOD}_{5} \\
\left(\mathrm{mg} \mathrm{O}_{2} \cdot \mathrm{dm}^{-3}\right)\end{array}$} & Mean \pm SD & $6.8 \pm 3.8$ & $4.3 \pm 2.1$ & $8.7 \pm 5.6$ & $7.2 \pm 2.8$ \\
\hline & Range & $1.0-16.2$ & $1.5-7.9$ & $2.7-22.4$ & $2.1-11.5$ \\
\hline & $\mathrm{CV}$ & 0.60 & 0.47 & 0.65 & 0.39 \\
\hline \multirow{3}{*}{$\begin{array}{l}\mathrm{NO}_{3} \\
\left(\mathrm{mg} \mathrm{NO}_{3} \cdot \mathrm{dm}^{-3}\right)\end{array}$} & Mean \pm SD & $0.14 \pm 0.18$ & $0.22 \pm 0.05$ & $0.34 \pm 0.37$ & $0.61 \pm 0.51$ \\
\hline & Range & $0.01-0.74$ & $0.15-0.32$ & $0.07-1.38$ & $0.08-1.42$ \\
\hline & $\mathrm{CV}$ & 1.29 & 0.23 & 1.08 & 0.84 \\
\hline \multirow{3}{*}{$\begin{array}{l}\mathrm{TP} \\
\left(\mathrm{mg} \mathrm{P}-\mathrm{PO}_{4} \cdot \mathrm{dm}^{-3}\right)\end{array}$} & Mean \pm SD & $3.16 \pm 2.96$ & $2.06 \pm 0.45$ & $0.43 \pm 0.39$ & $0.77 \pm 0.60$ \\
\hline & Range & $0.30-12.35$ & $1.00-2.70$ & $0.03-1.56$ & $0.12-1.76$ \\
\hline & $\mathrm{CV}$ & 0.94 & 0.21 & 0.90 & 0.77 \\
\hline
\end{tabular}

Table 2. Statistical characteristics of data sets - outflow waters from Syrenie Stawy (Pond No. 2)

\begin{tabular}{|c|c|c|c|c|c|}
\hline \multirow{2}{*}{$\begin{array}{l}\text { Water quality indices } \\
\text { (units) }\end{array}$} & \multirow{2}{*}{$\begin{array}{l}\text { Descriptive } \\
\text { Statistics }\end{array}$} & \multicolumn{4}{|c|}{ Year } \\
\hline & & 1994-1995 & 1999-2000 & 2006-2007 & 2014 \\
\hline \multirow{3}{*}{$\begin{array}{l}\text { Temperature } \\
\left({ }^{\circ} \mathrm{C}\right)\end{array}$} & Mean \pm SD & $11.6 \pm 7.2$ & $10.8 \pm 6.6$ & $16.5 \pm 4.2$ & $15.1 \pm 6.8$ \\
\hline & Range & $0.5-7.2$ & $2.5-25.0$ & $11.0-24.0$ & $0.6-25.2$ \\
\hline & $\mathrm{CV}$ & 0.62 & 0.62 & 0.25 & 0.45 \\
\hline \multirow{3}{*}{$\begin{array}{l}\mathrm{pH} \\
\text { (pH units) }\end{array}$} & Mean \pm SD & $7.8 \pm 0.62$ & $7.69 \pm 0.37$ & $7.76 \pm 0.46$ & $8.54 \pm 0.88$ \\
\hline & Range & $6.90-9.950$ & $7.10-8.70$ & $7.13-8.64$ & $7.10-9.89$ \\
\hline & $\mathrm{CV}$ & 0.08 & \begin{tabular}{|l|}
0.05 \\
\end{tabular} & 0.06 & 0.10 \\
\hline \multirow{3}{*}{$\begin{array}{l}\text { DO } \\
\text { (\% saturation) }\end{array}$} & Mean \pm SD & $73.6 \pm 50.3$ & $44.2 \pm 16.9$ & $57.7 \pm 16.7$ & $58.8 \pm 23.2$ \\
\hline & Range & $5.7-258.0$ & \begin{tabular}{|l|}
$12.0-76.0$ \\
\end{tabular} & \begin{tabular}{|l|}
$29.8-99.3$ \\
\end{tabular} & $23.5-103.4$ \\
\hline & $\mathrm{CV}$ & 0.68 & 0.38 & 0.68 & 0.40 \\
\hline \multirow{3}{*}{$\begin{array}{l}\mathrm{BOD}_{5} \\
\left(\mathrm{mg} \mathrm{O}_{2} \cdot \mathrm{dm}^{-3}\right)\end{array}$} & Mean \pm SD & $5.9 \pm 3.6$ & $4.3 \pm 3.6$ & $8.4 \pm 5.6$ & $5.9 \pm 3.15$ \\
\hline & Range & $0.1-15.8$ & \begin{tabular}{|c|}
$0.3-16.0$ \\
\end{tabular} & $2.9-22.4$ & $3.3-12.0$ \\
\hline & $\mathrm{CV}$ & 0.62 & 0.84 & 0.67 & 0.54 \\
\hline \multirow{3}{*}{$\begin{array}{l}\mathrm{NO} 3 \\
\left(\mathrm{mg} \mathrm{NO}_{3} \cdot \mathrm{dm}^{-3}\right)\end{array}$} & Mean \pm SD & $0.16 \pm 0.26$ & $0.17 \pm 0.06$ & $0.18 \pm 0.10$ & $0.44 \pm 0.53$ \\
\hline & Range & 0.01-1.24 & $0.05-0.30$ & \begin{tabular}{|l|}
$0.04-0.46$ \\
\end{tabular} & $0.09-1.75$ \\
\hline & $\mathrm{CV}$ & 1.67 & 0.35 & 0.54 & 1.19 \\
\hline \multirow{3}{*}{$\begin{array}{l}\mathrm{TP} \\
\left(\mathrm{mg} \mathrm{P}-\mathrm{PO}_{4} \cdot \mathrm{dm}^{-3}\right)\end{array}$} & Mean \pm SD & $2.02 \pm 2.99$ & $1.52 \pm 0.36$ & $0.46 \pm 0.28$ & $0.44 \pm 0.56$ \\
\hline & Range & 0.09-12.69 & \begin{tabular}{|l|}
$1.00-2.30$ \\
\end{tabular} & $0.15-1.20$ & $0.09-1.75$ \\
\hline & $\mathrm{CV}$ & 1.49 & 0.34 & 0.60 & 1.18 \\
\hline
\end{tabular}




\section{Results and discussion}

Test results are provided as a statistical characteristics of data sets in Table 1 and 2 and Figure 3. The NSF-WQI calculation results for various terms of water sampling - in Figure 4. In Figure 4 also indicated time periods of industrial wastewater inflow and wastewater carts wastewater discharges to the ponds Syrenie Stawy, as well as time periods of hydrotechnical works in 2003 and 2010-2012.

According to data from the years 1994-1995, 1999-2000, 2006-2007 and 2014 shown in Figure 3 water quality indices changed in a characteristic way, typical for shallow flow reservoir in the temperate climate zone (Dojlido, Best 1993). On the other hand - Figure 4 shows that the water quality index - although defined in a simplified manner, because without three of water quality indices (total suspended solids turbidity and fecal coliform), which was recommended for testing at work Rai et al. (2012) have a value in the range of 51-83 NSF-WQI points corresponding in range $51-70$ to medium to average quality and in range $71-83$ to good water quality. Further Figure 5 shows results of the difference between NSF-WQI values in the outflow area and NSF-WQI values in the water inflow area to the ponds Syrenie Stawy. In the above mentioned study periods the diversity of measurement data and NSF-WQI indicates that water quality of ponds Syrenie Stawy in the years 1994-1995 deteriorated as a result of periodic discharges of polluting substances, then in 1999-2000 was characterized by volatility indicators typical for the ecosystem during autosanation, as evidenced by similar values of water quality indices NSF-WQI in the inflow and outflow area of ponds Syrenie Stawy water. The water quality after 2000 was significantly worse compared with the period before 1999. The years 1999 to 2000 - was a time when the quality of water flowing into the ponds was better than the quality of water flowing out of ponds Syrenie Stawy.

Data presented in Figure 4 and Figure 5 indicates that ponds Syrenie Stawy fulfill their role as a retention reservoir, sedimentation and biological ponds - because often the water in outflow area have a better quality than the water in the inflow area to ponds Syrenie Stawy. However, in the result of the work of hydrotechnical works in 2003 and 2010 to 2012 years the quality of water flowing through the stream Osówka to ponds Syrenie Stawy - unfortunately deteriorated. 

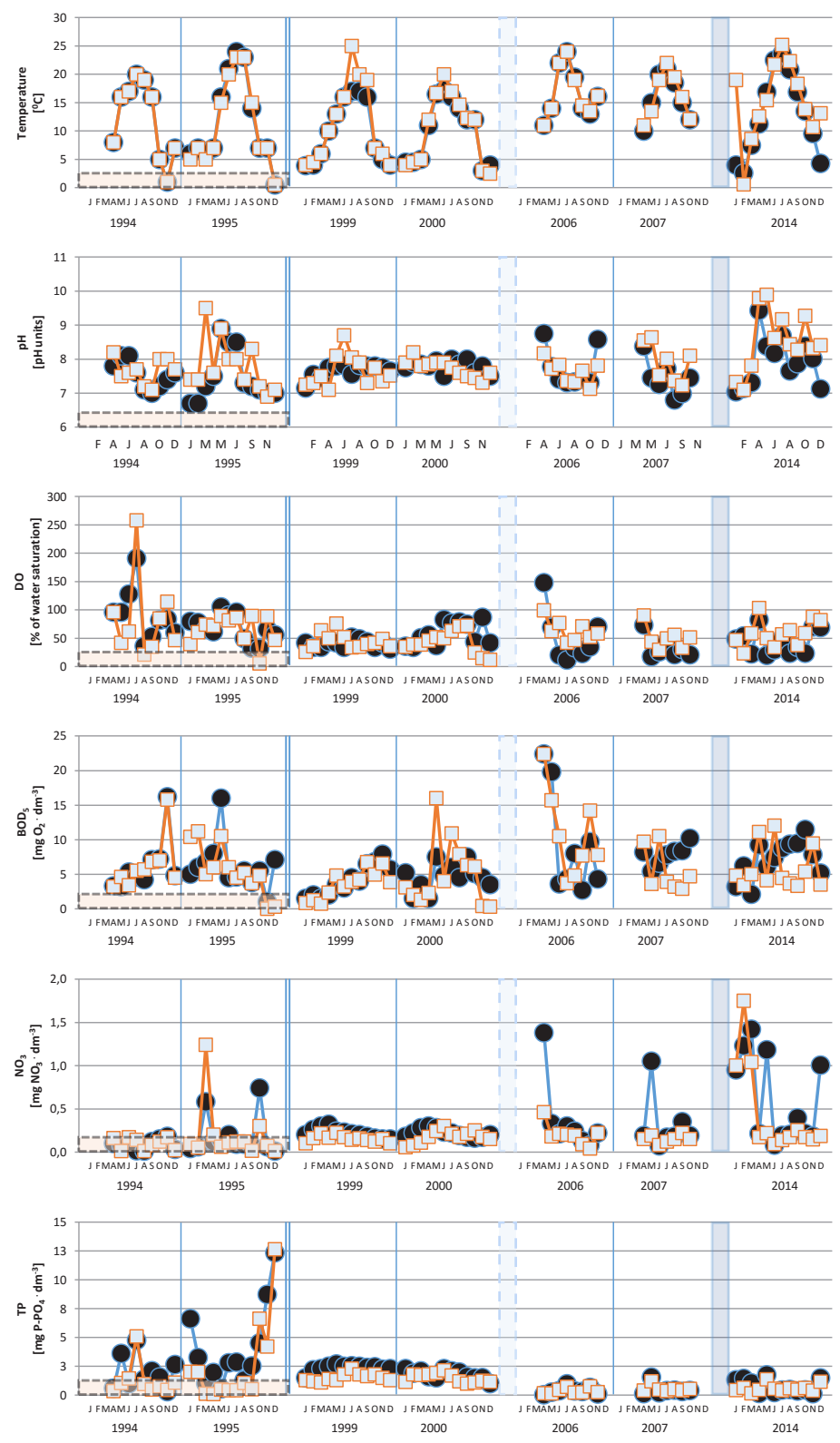

Figure 3. Quality indices of Stream Osówka waters in Syrenie Stawy ponds in inflow( $\bullet)$ and on outflow $(\square)$ stream waters area

- $* *$ Withdrawn gradually discharge of sewage from industrial plants and other sources

*Hydrotechnical regulations in year 2003

*Hydrotechnical regulations in years 2010-2012 


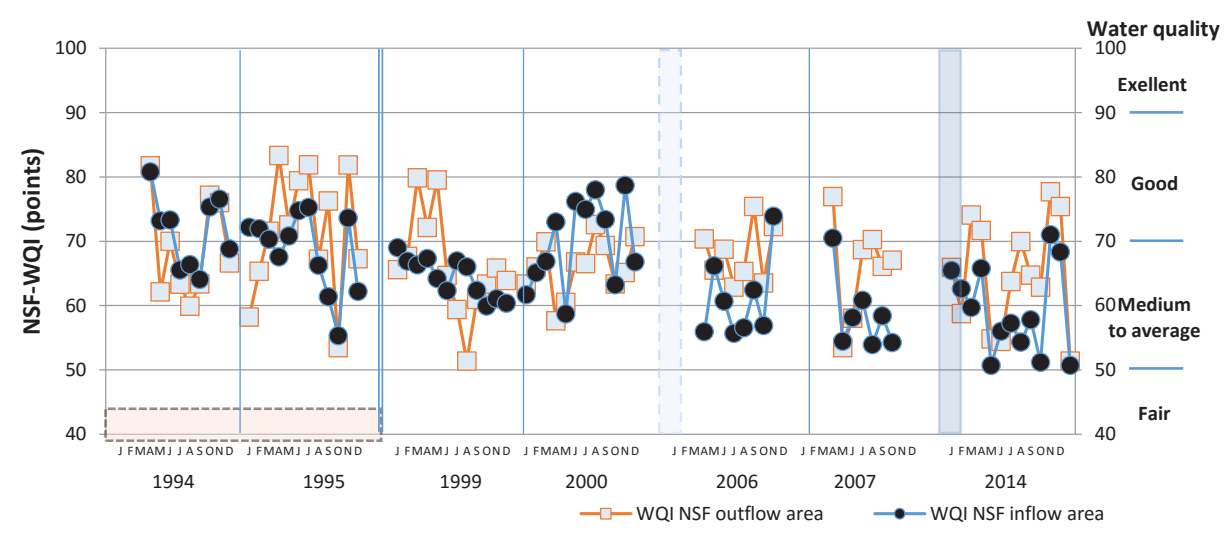

Figure 4. Syrenie Stawy waters - National Sanitation Foundation Water Quality Index (NSF-WQI)

- Withdrawn gradually discharge of sewage from industrial plants and other sources.

** Hydrotechnical regulations in year 2003.

* Hydrotechnical regulations in years 2010-2012.

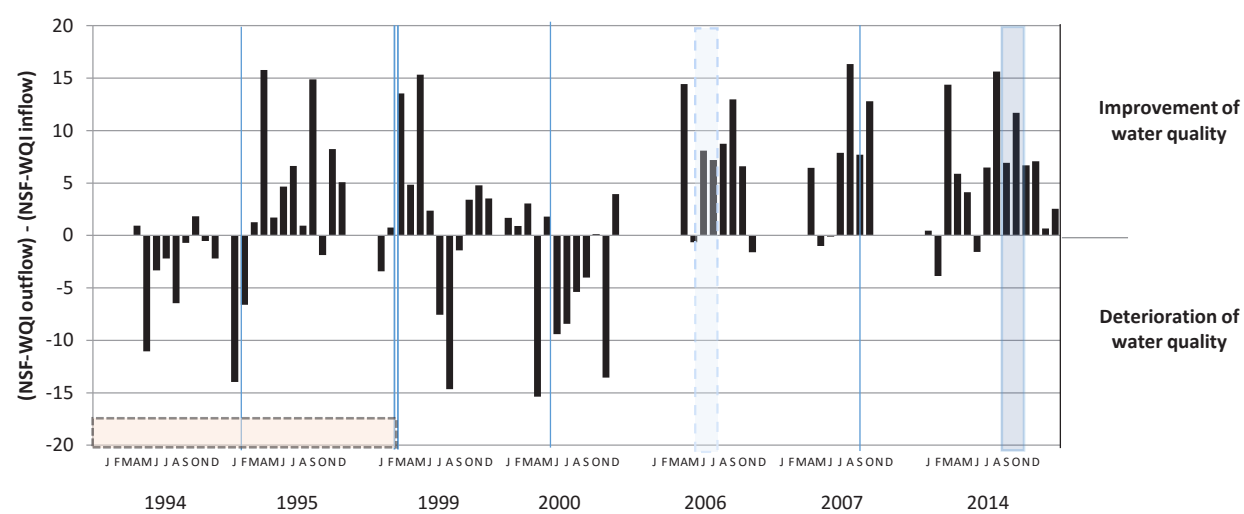

Figure 5. Changes in the value of surface water NSF-WQI as difference between outflow (NSF-WQI for outflow) and inflow area (NSF-WQI for inflow) to the Syrenie Stawy

Withdrawn gradually discharge of sewage from industrial plants and other sources.

* Hydrotechnical regulations in year 2003.

* Hydrotechnical regulations in years 2010-2012. 


\section{Conclusion}

Changes in NSF-WQI values specified for the Osówka stream water in the inflow and outflow area of water to and from the Syrenie Stawy, gives an indication that the tested water have NSF-WQI values ranging from 51 to 83 which corresponded to average and even good water quality - respectively. In our opinion it very well characterized by changes in water quality of Syrenie Stawy on the background change of anthropopressure, especially in the period of increased anthropopressure, after limiting the input of pollutants when the self-cleaning occurred in Ponds, and after two consecutive periods of carrying hydrotechnical works, when the deterioration of water quality in Syrenie Stawy, what exactly can be expected in connection with the release of pollution previously deposited in sediments. It has been shown that the usefulness of the application NSF-WQI to perform a quick assessment procedure in changes of water quality of the flowing water in to the ponds in long-time period based on a small number of studied basic water quality indices.

\section{References}

APHA. 1992. Standard methods for the examination of water and wastewater. American Public Health Association, Washington, 1800 pp.

Boyacioglu H. 2007. Development of a water quality index based on a European classification scheme. Water SA, 33 (1): 101-106.

Boyacioğlu H., Gündoğdu V. 2013. Efficiency of Water Quality Index Approach as an Evaluation Tool. Ecological Chemistry and Engineering S, 20 (2): 247-255. DOI: 10.2478/eces-2013-0017.

Brown R.M., McClelland N.I., Deininger R.A., Tozer R.G. 1970. Water quality index do we dare? Water Sewage Works, 117 (10): 339-343.

Cude C.G. 2001. Oregon water quality index: A tool for evaluating water quality management. Journal of the American Water Resources Association, 37 (1): 125-137.

Dojlido J., Raniszewski J., Woyciechowska J. 1994. Water Quality index applied to rovers in the Vistula River basin in Poland. Environmental Monitoring and Assessment, 33: $33-42$.

Dojlido J.R, Best G.A. 1993. Chemistry of Water and Water Pollution, Ellis Horwood, Hemel Hempstead.

Dos Santos Simoes F., Moreira A.B., Bisinoti M.C., Gimenez S.M.N., Yabe M.J.S. 2008. Water quality index as a simple indicator of aquaculture effects on aquatic bodies. Ecological Indicators, 8 (5): 476-484. DOI: 10.1016/j.ecolind.2007.05.002. 
European Commission. 2008. Directive 2008/105/EC of the European Parliament and the Council on environmental quality standards in the field of water policy, amending and subsequently repealing Council Directives 82/176/EEC, 83/513/EEC, 84/156/ EEC, 84/491/EEC, 86/280/EEC and amending Directive 2000/60/EC, Official Journal, 24.12.2008.

Farzadkia M., Djahed B., Shahsavani E., Poureshg Y. 2015. Spatio-temporal evaluation of Yamchi Dam basin water quality using Canadian water quality index. Environmental Monitoring and Assessment, 187 (4): 1-15. DOI: 10.1007/s10661-015-4379-8.

House M.A. 1989. A Water-Quality Index for River Management. Water and Environmental Journal, 3 (4): 336-344.

Javid A., Yaghmaeian K., Abbasi E., Roudbari A. 2014. An evaluation of water quality from Mojen River, by NSF-WQI index. Journal of Ecological Engineering, 15 (4): 1-6. DOI: 10.12911/22998993.1125451.

Kumar D., Alappat B. 2009. NSF-Water Quality Index: Does It Represent the Experts' Opinion? Practice Periodical of Hazardous, Toxic, and Radioactive Waste Management, 13 (1): 75-79. DOI: 10.1061/(ASCE)1090-025X(2009)13:1(75).

Landwehr J.M., Deininger R.A. 1976. A comparision of several water quality indices. Journal of the Water Pollution Control Federation, 48 (5): 954-958.

Miller T., Tokarz M., Poleszczuk G. 2014. Stream Osówka in Szczecin - chemometric analysis of water quality indices in winter season. Acta Biologica, 21: 91-104, www.wb.usz.edu.pl/attachments/article/657/6-Miller.pdf.

Poleszczuk G., Wawrzyniak W., Miller T., Tokarz M., Gasperowicz A., Adamczyk D. 2014. Syrenie Stawy w Szczecinie - porównanie jakości wód w okresie zimowym i wiosennym w latach 1994-1995, 1999-2000, 2006-2007 i 2014. In: Pogranicze Bezpieczeństwa Człowieka. W. Wawrzyniak, T. Zaborowski (eds.). Gorzów Wlkp.Poznań, pp. 122-137. DOI: 10.13140/2.1.2179.2006.

Poleszczuk G. 2003. Ocena klasowości wód Syrenich stawów w Szczecinie (według kryteriów systemu oceny jakości jezior SOOJ) w roku 2001, Acta Biologia, 10: 161-173.

Rai R.K., Upadhyay A., Ojha C.S.P., Singh V.P. 2012. The Yamuna River Basin. Water Science and Technology Library, 66: 307-356. DOI: 10.1007/978-94-007-2001$5 \_11$.

Rozporządzenie Ministra Środowiska z dnia 22 października 2014 r. w sprawie sposobu klasyfikacji stanu jednolitych części wód powierzchniowych oraz środowiskowych norm jakości dla substancji priorytetowych - Dz.U. 2014 poz. 1482.

Sánchez E., Colmenarejo M.F., Vicente J., Rubi, A., García M.G., Travieso L., Borja R. 2007. Use of the water quality index and dissolved oxygen deficit as simple indicators of watersheds pollution. Ecological Indicators, 7 (2): 315-328. DOI:10.1016/j. ecolind.2006.02.005. 
Tallar R.Y., Suen J.P. 2015. Aquaculture Water Quality Index: a low-cost index to accelerate aquaculture development in Indonesia. Aquaculture International: 1-18. DOI: 10.1007/s10499-015-9926-3.

Tyagi S., Sharma B., Singh P., Dobhal R. 2013. Water quality assessment in terms of water quality index. American Journal of Water Resources, 1(3): 34-38. DOI: 10.12691/ajwr-1-3-3.

Zdunkiewicz K. 1981. Zastosowanie uogólnionego wskaźnika WQI do oceny jakości wody powierzchniowej. Ochrona Środowiska, 3: 18-22.

\section{Appendix}

\section{National Sanitation Foundation Water Quality Index (NSF-WQI) - calculation procedure used in these paper}

During the year 1970, a Water Quality Index (WQI) was developed at the National Sanitation Foundation (NSF). It appears to be the most comprehensive form of WQI, named NSF-WQI (Brown et al. 1972, Landwehr, Deininger, 1976, Rai et al. 2012).

The NSF-WQI mathematically can be expressed as follows:

$$
N S F W Q I=\sum_{i=1}^{n} Q_{i} W_{1}
$$

where:

$Q_{i}-$ sub-index of i-th water quality indices,

$W_{i}-$ weight of $\mathrm{i}$-th water quality indices,

$n$ - number of used water quality indices used in calculations.

NSF-WQI is a 100 point scale that summarizes results from a total of nine different parameters. NSF procedure for calculating the WQI expected determination of the nine water quality indices in water sample: temperature change, $\mathrm{pH}$, dissolved oxygen (as water saturation \%), biochemical oxygen demand, nitrate, total phosphate, total suspended soils, turbidity and fecal coliform. It is acceptable to calculate the NSF-WQI based on a smaller number of parameters (Rai et al. 2012). When all parameters are not measured (i.e. only 5 out of 9) then the weights are adjusted.

In this work calculation of NFS-WQI based on the measurements results of 6 from 9 above water quality indices, especially: temperature change, $\mathrm{pH}$, dis- 
solved oxygen, biochemical oxygen demand, nitrate, total phosphate. NSF-WQI values calculated on the basis of less than 9 parameters is calculated as follows (Rai et al. 2012: 317).

$$
N S F W Q=\sum_{i=1}^{n} Q_{i} W_{i} \cdot\left(\sum_{i=1}^{n} W_{i}\right)^{-1}
$$

Subsequently calculations performed on the procedure taken from the work Rai et al. (2012: 310-316). In this study, calculations were performed in order:

\section{A) Step I - calculation of $Q_{i}$}

\section{a) Temperature change $(\Delta T)$}

$Q_{\Delta \mathrm{T}}=3,8 \Delta T+93$; if $-10 \leq \Delta \mathrm{T} \leq 0$

$Q_{\Delta \mathrm{T}}=-5,6 \Delta T+101 ;$ if $0<\Delta \mathrm{T} \leq 10$

$Q_{\Delta \mathrm{T}}=-2,8 \Delta T+73 ;$ if $10<\Delta \mathrm{T} \leq 15$

$Q_{\Delta \mathrm{T}}=-1,8 \Delta T+58 ;$ if $15<\Delta \mathrm{T} \leq 20$

$Q_{\Delta \mathrm{T}}=-1,2 \Delta T+46 ;$ if $20<\Delta \mathrm{T} \leq 30$

$\Delta \mathrm{T}$ - change in temperature- referring to change in temperature between control points (station No. 1 and station No. 2).

\section{b) $\mathbf{p H}$}

$Q_{p H}=0,0$; if $p H<2,00$

$Q_{p H}=-0,0799 p H^{5}+1,3838 p H^{4}-8,115 p H^{3}+21,389 p H^{2}-23,761 p H+9,209$; if $2,00<\mathrm{pH}<7,50$

$\mathrm{Q}_{p H}=0,0 ;$ if $p H>12,00$

$$
\begin{aligned}
& \text { c) Dissolved oxygen as water saturation }\left(\% \mathbf{D O}_{\text {sat }}\right) \\
& Q_{D O}=0,0 ; \text { if } \% D O_{\text {sat }} \leq 0,0 \\
& Q_{D O}=47,54 \cos \left[0,03103\left(\% D O_{\text {sat }}\right)-3,282\right]+50,96 \text {; if } 0<\% D O_{\text {sat }} \leq 140,0 \\
& Q_{D O}=50,0 ; \text { if } \% D O_{\text {sat }} \geq 140,0
\end{aligned}
$$

d) Biochemical Oxygen Demand - as five day test in $\mathbf{m g O}_{\mathbf{2}} \cdot \mathbf{d m}^{-3}\left(\mathrm{BOD}_{\mathbf{5}}\right)$

$Q_{B O D}=-0,2311(B O D)^{4}+3,0227(B O D)^{3}-11,754(B O D)^{2}+3,3994(B O D)$

$$
+100 \text {; if } B O D<5,0
$$




$$
\begin{aligned}
Q_{B O D}= & -0,027(B O D)^{3}+0,236(B O D)^{2}-7,4486(B O D)+87,674 ; \\
& \text { if } 5,0<B O D<30,0 \\
Q_{B O D}= & 2,0 ; \text { if } B O D \geq 30
\end{aligned}
$$

\section{e) Nitrate in $\mathbf{m g ~ N O} \mathbf{N}_{3} \cdot \mathbf{d m}^{-3}\left(\mathrm{NO}_{3}^{-}\right)$}

$Q_{\mathrm{NO}_{3}}=28,0 \exp \left[-0,27\left(\mathrm{NO}_{3}\right)\right]+72,0 \exp \left[-0,035\left(\mathrm{NO}_{3}\right)\right]$; if $0 \leq N O_{3} \leq 100$

$Q_{\mathrm{NO}_{3}}=1$; if $\mathrm{NO}_{3}>100$

\section{f) Total phosphate in $\mathrm{mg} \mathrm{P} \cdot \mathbf{d m}^{-3}$ (TP)}

$Q_{T P}=98,37-316,5 T P^{2} \frac{0,01637}{T P} ;$ if $0,01<T P<0,09$

$Q_{T P}=35,22 \exp \left[\frac{0,3312}{T P}-0,2135 T P\right] ;$ if $1,0 \leq T P \leq 7,5$

$Q_{T P}=7 ;$ if $7,5<T P \leq 10,0$

$Q_{T P}=2$; if $T P>10,0$

\section{B) Step II - weights $\left(W_{i}\right)$ used for calculation (Tab A)}

Table A. Weights $\left(W_{i}\right)$ of water quality indices used in NSF-WQI model in these study (after Rai et al. 2012: 308)

\begin{tabular}{|c|l|c|}
\hline No. & \multicolumn{1}{|c|}{ Physicochemical water quality indices } & Weight $\left(W_{i}\right)$ \\
\hline 1. & Temperature change & 0.10 \\
\hline 2. & pH & 0.11 \\
\hline 3. & Dissolved oxygen & 0.17 \\
\hline 4. & BOD & 0.11 \\
\hline 5. & Nitrates & 0.10 \\
\hline 6. & Total phosphate & 0.08 \\
\hline
\end{tabular}

\section{C) Step III - Calculation of NSF-WQI}

In our case number (n) of used water quality indices used in calculations were

6. In comparison with the calculation procedures in the work Rai et al. (2012: 317 ) - skipped in the calculation 3 water quality indices in particular: the total suspended solids, turbidity, and fecal coli form.

In cases where we do not have all the results of nine water quality parameters creating sub-indexes in the model NSF-WQI the relative weights for each factor are preserved, and the total scale in the range from 0 to 100 , and then the calcu- 
lation formula assumes the form (Rai et al. 2012) - which was used in presented study Eq. 1 and Eq. 2.

Eq. 1 and Eq. 2. allows to obtain values of water quality on a scale from 0 to 100. Depending on the values which will be derived from the calculation result is attributed to him an adequate assessment of water quality, as in Table A (House 1989; Rai et al. 2012):

\section{D) Step IV - Defining a class of water quality based on NSF-WQI - values} from Table B

Table B. Water class based on NSF-WQI (House 1989; Rai et al. 2012)

\begin{tabular}{|l|l|l|}
\hline $\begin{array}{c}\text { NSF-WQI } \\
\text { value } \\
\text { (points) }\end{array}$ & $\begin{array}{l}\text { Water Quality } \\
\text { assessment }\end{array}$ & \multicolumn{1}{|c|}{ Class description } \\
\hline $91-100$ & exelent & $\begin{array}{l}\text { water quality is protected with total absence of risks; } \\
\text { conditions similar to the natural or original }\end{array}$ \\
\hline $71-90$ & good & $\begin{array}{l}\text { the water quality is protected but only with small threats or } \\
\text { decreased; rarely differs from natural or desirable levels }\end{array}$ \\
\hline $51-70$ & medium to & $\begin{array}{l}\text { water quality is usually protected but occasionally threatened } \\
\text { or decreased; sometimes it differs from natural or desirable } \\
\text { levels }\end{array}$ \\
\hline $26-50$ & fair & $\begin{array}{l}\text { water quality is often threatened or significantly reduced; they } \\
\text { differ from natural or desirable levels }\end{array}$ \\
\hline $0-25$ & poor & $\begin{array}{l}\text { water quality is always threatened; they differ from natural or } \\
\text { desirable levels }\end{array}$ \\
\hline
\end{tabular}




\section{ZMIANY JAKOŚCI WÓD STRUMIENIA OSÓWKA PRZEPLYWAJĄCEGO PRZEZ SYRENIE STAWY W SZCZECINIE (PÓLNOCNO-ZACHODNIA POLSKA) W WYBRANYCH OKRESACH W LATACH 1994-2014}

\section{Streszczenie}

Celem rozeznania zmian jakości wód strumienia Osówka przepływających przez Syrenie Stawy w Szczecinie (północno-zachodnia Polska) prowadzono w latach 1994-2014 badania podstawowych wskaźników jakości wód, w stresie dopływu wód strumienia Osówka oraz w strefie odpływu wód do/z zbiorników Syrenich Stawów, które wykorzystano do obliczania wartości National Sanitation Foundation Water Quality Index (NSF -WQI). Wartości NFS-WQI obliczano na podstawie oznaczeń temperatury, pH, stężenia rozpuszczonego tlenu (jako procent natlenienia), $\mathrm{BOD}_{5}$, stężeń azotanów (V) i ogólnych fosforanów wykonywanych w latach 1994-1995, 1999-2000, 2006-2007 oraz 2014, tj. w wybranych okresach, a w szczególności podczas spadku ilości dopływających zanieczyszczeń przemysłowych i po zmianach wielkości antropopresji związanej z prowadzeniem regulacji hydrotechnicznych cieku Osówka i Syrenich Stawów. Oceniając według kryteriów procedury NFS-WQI - jakość badanych wód odpowiadała dobrej bądź średniej jakości. Na podstawie wielkości i zmian wartości wskaźników NSF-WQI wykazano, że jakość przepływających przez Syrenie Stawy wód w kolejnych okresach pomiarowych była coraz gorsza, równocześnie efekt samooczyszczania się wód wzdłuż drogi ich spływu przez Syrenie Stawy stopniowo wzrastał, szczególnie po regulacjach hydrotechnicznych. Oceniono, że stosowanie procedury NSF-WQI do oceny jakości i rozeznawania zmian jakości wód w stawach przepływowych w wieloleciach, bazujące na wynikach oznaczeń ilości podstawowych fizyczno-chemicznych wskaźników jakości wód może być przydatne do stosowania w praktyce.

Słowa kluczowe: miejskie stawy, indeks jakości wody NFS-WQI, strumień Osówka, Syrenie Stawy, miasto Szczecin

Cite this article as: Miller T., Poleszczuk G., Tokarz M. 2015. Changes of water quality of the Osówka Stream flowing through ponds Syrenie Stawy in Szczecin (NW-Poland) in selected periods in the years 1994-2014. Acta Biologica, 22: 137-152. 